\title{
Evaluation of D-Dimer Level in Sudanese Patients with Chronic Liver Disease in IbnSina Hospital
}

\author{
Rehab Abdul Kareem Ahmed Al-Basheer ${ }^{1}$, Amira Ahmed Khalid Humeida² \\ ${ }^{1}$ Department of Hematology, Faculty of Medical Laboratory Sciences, Al-Neelain University, Khartoum, Sudan \\ ${ }^{2}$ Department of Pathology, Faculty of Medicine, Al-Neelain University, Khartoum, Sudan \\ Email: wrd-alkhmel25@hotmail.com
}

How to cite this paper: Al-Basheer, R.A. K.A. and Humeida, A.A.K. (2017) Evaluation of D-Dimer Level in Sudanese Patients with Chronic Liver Disease in IbnSina Hospital. Open Journal of Internal Medicine, 7, 74-79.

https://doi.org/10.4236/ojim.2017.73008

Received: May 31, 2017

Accepted: September 11, 2017

Published: September 14, 2017

Copyright (c) 2017 by authors and Scientific Research Publishing Inc. This work is licensed under the Creative Commons Attribution International License (CC BY 4.0).

http://creativecommons.org/licenses/by/4.0/

\begin{abstract}
Background: Chronic liver disease is a disease process of the liver that involves a process of progressive destruction and regeneration of the liver parenchyma leading to fibrosis and cirrhosis chronic liver disease refers to disease of the liver which had lasted over a period of 6 months. This study was conducted to evaluate the D-dimer levels among Sudanese patients with Chronic Liver Diseases. Materials and Method: In IbnSina hospital, Khartoum state, Sudan, a case control study was conducted. For this study, 100 participants were selected, 70 of them were patients known diagnosed by chronic liver diseases as a test group. Other 30 participants were normal healthy individual as control group. The plasma D-dimer level was measured by using MINDRAY auto analyzer BS 380). Results: In this study, the plasma $\mathrm{D}$-dimer level has statistically significantly higher in chronic liver diseases patients (mean \pm SD $0.634 \pm 0.215 \mathrm{ug} / \mathrm{l}$ ) compared to normal healthy control group (mean \pm SD $0.223 \pm 0.077 \mathrm{ug} / \mathrm{l}$ ) with $\mathrm{P}$ value 0.000 . Conclusion: The present study revealed that the $\mathrm{D}$-dimer levels were statistically significant higher in chronic liver diseases patients.
\end{abstract}

\section{Keywords}

Chronic Liver Disease, Coagulation, D-Dimer, Sudan

\section{Introduction}

Hemostasis is a dynamic process resulting from the balance between procoagulant and anticoagulant factors. The liver is an important organ that synthesizes coagulation factors, (except the von Willebrand factor); fibrinolytic system proteins, 
(except the tissue plasminogen factor); and the urokinase-type plasminogen activator; as well as coagulation and fibrinolysis inhibitors. In patients with hepatic parenchymal disease, the loss of functional parenchyma results in decreased synthesis of both coagulation factors and natural anticoagulant proteins.

Chronic liver disease in the clinical context is a disease process of the liver that involves a process of progressive destruction and regeneration of the liver parenchyma leading to fibrosis and cirrhosis [1].

Hemostasis is a balance between pro-coagulant and anti-coagulant forces [2]. The liver is the site of synthesis of several proteins which are involved in the process of coagulation such as prothrombin and fibrinogen [3] [4]. Liver function tests include standard laboratory tests to help in the evaluation of coagulopathy in liver disease.

The determination of prothrombin time (PT) or international normalized ratio (INR), activated partial thromboplastin time (APTT), and fibrinogen are generally carried out in order to assess the coagulation status of patients with chronic liver disease. This becomes particularly important when a patient with a history of chronic liver disease has to undergo any surgery, in order to assess the risk of bleeding. While there are several tests which assess the coagulation status tests there are no tests which are routinely carried out in order to assess the fibrinolytic status, a process which can have an impact upon the bleeding tendency of these patients. Coagulation followed by fibrinolytic activity leads to a fall in the levels of fibrinogen with a concomitant rise in the levels of fibrin degradation products [FDP's] [5].

D-dimer is a stable and measurable parameter formed by the enzymatic breakdown of the cross-linked fibrin. Estimation of D-dimer even today has been used for the diagnosis of conditions such as deep vein thrombosis and pulmonary embolism [6] [7].

Since chronic liver disease is associated with disordered hemostasis, it is possible that it could be associated not only with defects in coagulation but also of clot lysis. Estimation of D-dimer might provide some insight into possible derangements in the fibrinolytic pathway, increased D-dimer levels which is a measurable parameter for assessing the entire fibrinolytic system [8] [9].

Estimation of D-dimer even today has been used for the diagnosis of conditions such as deep vein thrombosis and pulmonary embolism [6] [10].

\section{Materials and Methods}

This case control study was conducted in IbnSina Hospital in Khartoum state from October 2016 to August 2017.

A total of 70 Sudanese patients with CLD were enrolled to participate in this study and 30 subjects as control group, patients included in this study were both males and females diagnosed with CLD by Liver Function Test, liver biopsy, any causes of high D-dimer levels such as DIC, heart disease, trauma, recent surgery and patients with clinical thrombosis were excluded. 
About $5 \mathrm{~mL}$ blood sample were collected from each subject into Trisodium citrate anticoagulant containers, the plasma was separated and analysis for D. Dimer were assessed by using NycoCard Reader II, Prothrombin Time assessed by coagulometer and Albumin Level, Bilirubin Level, which were measured using ((MINDRAY auto analyzer BS 380).

This study was approved by the faculty of medical laboratory sciences, Al neelain University, Department of Hematology and informed consent was obtained from each participant before sample collection, data collection was done using questionnaire.

Data analysis was performed using SPSS (Statistical Package for the Social Science) Version 20.0 statistical software. Dependent variables, mean, standard deviation, $\mathrm{T}$ test, Pearson and spearman test were calculated, $\mathrm{P}$ values $<0.05$ were considered as statistically significant.

\section{Results}

The mean and Standard Deviation of D-dimer in patients were $0.634 \pm 0.215$ $\mathrm{ug} / \mathrm{l}$ and in control was $0.223 \pm 0.077 \mathrm{ug} / \mathrm{l}$, with a $(\mathrm{P}$-value $=0.000)$ (Table 1$).$ In this study, and in males mean and Standard Deviation of D-dimer were $0.646 \pm$ $0.205 \mathrm{ug} / \mathrm{l}$ and the mean in females was $0.605 \pm 0.239 \mathrm{ug} / \mathrm{l}$ with a $(\mathrm{P}$-value $=$ 0.474) (Table 2).

The bilirubin was measured in patients with chronic liver disease and in control and we found the mean and Standard Deviation was $2.116 \pm 0.478 \mathrm{mg} / \mathrm{dl}$ and $0.703 \pm 0.316 \mathrm{mg} / \mathrm{dl}$ in patients and control groups respectively with a $(\mathrm{P}$-value $=0.000)($ Table 1$)$. The mean of bilirubin level in males was $1.250 \pm$ $0.237 \mathrm{mg} / \mathrm{dl}$, and the mean in females was $2.070 \pm 0.444 \mathrm{mg} / \mathrm{dl}$ with a $(\mathrm{P}$-value $=$ 0.601) (Table 2).

Table 1. Mean concentration levels comparison of D-dimer, Albumin, Bilirubin and PT in case and control group.

\begin{tabular}{cccc}
\hline Parameters & Case $(\mathrm{M} \pm \mathrm{STD})$ & Control $(\mathrm{M} \pm \mathrm{STD})$ & P value \\
\hline D-dimer & $0.634 \pm 0.215 \mathrm{ug} / \mathrm{l}$ & $0.223 \pm 0.077 \mathrm{ug} / \mathrm{l}$ & 0.000 \\
Albumin level & $1.780 \pm 1.744 \mathrm{~g} / \mathrm{dl}$ & $4.270 \pm 0.571 \mathrm{~g} / \mathrm{dl}$ & 0.000 \\
Bilirubin level & $2.116 \pm 0.478 \mathrm{mg} / \mathrm{dl}$ & $0.703 \pm 0.316 \mathrm{mg} / \mathrm{dl}$ & 0.000 \\
PT & $40.214 \pm 9.508 \mathrm{sec}$ & $11.643 \pm 1.275 \mathrm{sec}$ & 0.000
\end{tabular}

Table 2. Relationship between mean and STD of D-dimer, Albumen, Bilirubin and PT between males and females.

\begin{tabular}{cccc}
\hline Parameters & Male $(\mathrm{M} \pm \mathrm{STD})$ & Female $(\mathrm{M} \pm \mathrm{STD})$ & P value \\
\hline D-dimer & $0.646 \pm 0.205 \mathrm{ug} / \mathrm{l}$ & $0.605 \pm 0.239 \mathrm{ug} / \mathrm{l}$ & 0.474 \\
Albumin level & $1.952 \pm 0.039 \mathrm{~g} / \mathrm{dl}$ & $1.250 \pm 0.237 \mathrm{~g} / \mathrm{dl}$ & 0.044 \\
Bilirubin level & $1.250 \pm 0.237 \mathrm{mg} / \mathrm{dl}$ & $2.070 \pm 0.444 \mathrm{mg} / \mathrm{dl}$ & 0.601 \\
PT & $40.460 \pm 9.119 \mathrm{sec}$ & $39.600 \pm 10.644 \mathrm{sec}$ & 0.753 \\
\hline
\end{tabular}


Table 3. Correlation study between D-dimer and study variables.

\begin{tabular}{lcccc}
\hline \multicolumn{2}{c}{ Parameters } & Albumen level & Bilirubin level & PT \\
\hline \multirow{2}{*}{ D-dimer } & R-value & -0.272 & 0.264 & 0.056 \\
& P-value & 0.023 & 0.027 & 0.648 \\
\hline
\end{tabular}

In the present study, in patients with CLD, the mean and Standard Deviation of albumin level were $1.780 \pm 1.744 \mathrm{~g} / \mathrm{dl}$ and $4.270 \pm 0.571 \mathrm{~g} / \mathrm{dl}$ in control with a $(\mathrm{P}$-value $=0.000)($ Table 1$)$. Mean of albumin in males and females was $1.952 \pm$ $0.039 \mathrm{~g} / \mathrm{dl}$ and $1.250 \pm 0.237 \mathrm{~g} / \mathrm{dl}$ respectively with a $(\mathrm{P}-$ value 0.044$)$ (Table 2 ).

The PT was also determined giving a mean and Standard Deviation of PT in patients of $40.214 \pm 9.508$ seconds while in control was $11.643 \pm 1.275$ seconds with a $(\mathrm{P}$-value $=0.000)($ Table 1$)$. The mean of $\mathrm{PT}$ in males was $40.460 \pm 9.119$ seconds, and mean in females was $39.600 \pm 10.644$ seconds with a $(\mathrm{P}$-value $=$ 0.753) (Table 2).

Correlation study between $\mathrm{D}$-dimer and Albumen level R-value $(-0.272)$ $\mathrm{P}$-value (0.023), Bilirubin level R-value (0.264) $\mathrm{P}$-value (0.027), PT P-value (0.648), R-value (0.056) (Table 3).

\section{Discussion}

In this is study, $72 \%$ of patients with CLD showed elevated in D-dimer level, when compared with control, no statistically significant differences as regard age and sex.

Our present study showed that statistically negative correlated with albumin level and positively correlated with plasma D-dimer, bilirubin level, and Prothrombin time in patients with chronic liver disease and this agree with Wesam A. Ibrahim, Sara Abdelhakam et al. in 2011 [11].

Our finding is in concordance with that of Agarwal et al who reported increased plasma D-Dimer in $63 \%$ of patients with liver cirrhosis [12].

Spadero et al. (2008) also reported high D-dimer level in $63 \%$ of patients with of liver disease [13].

Dhanunjaya et al., J in 2013, who studied 99 patients with Chronic Liver Disease and found that was to be strongly increased significantly with severity of liver disease [14].

Turk J Gastroenterol. 2005 sep, who recruited 50 patients with CLD found that to be increased D-dimer level with cirrhotics in comparison with controls, this is Similar findings, with higher D-Dimer level had previously been reported [15].

In the current study, there was highly significantly positive correlation between plasma D-dimer and patient with chronic liver disease. This is agreed with that of Primignani et al. (2017) who found that D-dimer level was significantly more elevated in CLD [16].

This is study showed the correlation between D-dimer level, albumin level, bilirubin level and PT and found that, these was D-dimer inversely proportional to 
albumin level and directly proportion to bilirubin level and PT.

\section{Conclusion}

In conclusion, the study reported the increased levels of D-dimer in Chronic Liver Disease among Sudanese patients.

\section{References}

[1] NHS Choices. Cirrhosis. Retrieved 6 October 2015.

[2] Violi, F., Ferro, D., Basili, S., Quintarelli, C., Alessandri, C., et al. (1992) Hyperfibrinolysis Increases the Risk of Gastrointestinal Hemorrhage in Patients with Advanced Cirrhosis. Hepatology, 15, 672-676. https://doi.org/10.1002/hep.1840150420

[3] Broohy, M.T., Fiorel and Deykin, D. (1996) Hemostasis. In: Zakim Boyer, T.D., Ed., Hepatology: A Textbook of Liver Disease, 3rd Edition, WB Saunders, Philadelphia, 691-719.

[4] Van Thiel, D.H., George, M., Mindikoglu, A.L., Baluch, M.H. and Dhillon, S. (2004) Coagulation and Fibrinolysis in Individuals with Advanced Liver Disease. The Turkish Journal of Gastroenterology, 15, 67-72.

[5] Hunt, B.J. and Segal, H. (1996) Hyperfibrinolysis. Journal of Clinical Pathology, 49, 958. https://doi.org/10.1136/jcp.49.12.958

[6] Reber, G. and De Moerloose, P. (2000) D-Dimer Assays for the Exclusion of Venous Thromboembolism. Semin Thromb Hemost, 26, 619-624.

https://doi.org/10.1055/s-2000-13217

[7] Kline, J.A., Johns, K.L., Colucciello, S.A. and Israel, E.G. (2000) New Diagnostic Tests for Pulmonary Embolism. Annals of Emergency Medicine, 35, 168-180. https://doi.org/10.1016/S0196-0644(00)70137-5

[8] Dhanunjaya, Y., Anand, U. and Anand, C.V. (2013) A Study of Plasma D-Dimer Levels in Various Stages of Liver Diseases. Journal of Liver, 2, 119. https://doi.org/10.4172/2167-0889.1000119

[9] Caldwell, S.H., Hoffman, M. and Lisman, T. (2006) Coagulation Disorders and Hemostasis in Liver Disease: Pathophysiology and Critical Assessment of Current Management. Hepatology, 44, 1039-1046. https://doi.org/10.1002/hep.21303

[10] Kline, J.A., Johns, K.L., Colucciello, S.A. and Israel, E.G. (2000) New Diagnostic Tests for Pulmonary Embolism. Annals of Emergency Medicine, 35, 168-180. https://doi.org/10.1016/S0196-0644(00)70137-5

[11] Wesam A. Ibrahim, Sara Abdelhakam et al in 2011 Kasr Al-Ainy International Publication.

[12] Agarwal, S., Joyner Jr., K.A. and Swaim, M.W. (2000) Ascites Fluid as a Possible Origin for Hyperfibrinolysis in Advanced Liver Disease. The American Journal of Gastroenterology, 95, 3218-3224. https://doi.org/10.1111/j.1572-0241.2000.03299.x

[13] Spadaro et al. (2008) High Circulating D-Dimers Are Associated with Ascites and Hepatocellular Carcinoma in Liver Cirrhosis. World Journal of Gastroenterology, 14, 1549-1552.

[14] Wells, P.S., Anderson, D.R., Rodger, M., Forgie, M., Kearon, C., Dreyer, J., Kovacs, G., Mitchell, M., Lewandowski, B. and Kovacs, M.J. (2003) Evaluation of D-Dimer in the Diagnosis of Suspected Deep-Vein Thrombosis. The New England Journal of Medicine, 349, 1227-1235. (Dhanunjaya et al., J Liver in 2013, who demonestrate 99 patients with CLD) https://doi.org/10.1056/NEJMoa023153 
[15] Moons, K.G., Gonias, S.L., Rose, C.E. and Bruns, D.E. (2005) The Turkish Journal of Gastroenterology, Sep., PMID1292822.

[16] Li, Y., Qi, X.S., Li, H.Y., et al. (2017) D-Dimer Level for Predicting the In-Hospital Mortality in Liver Cirrhosis. Experimental and Therapeutic Medicine, 13, 285-289. https://doi.org/10.3892/etm.2016.3930

\section{Scientific Research Publishing}

Submit or recommend next manuscript to SCIRP and we will provide best service for you:

Accepting pre-submission inquiries through Email, Facebook, LinkedIn, Twitter, etc. A wide selection of journals (inclusive of 9 subjects, more than 200 journals)

Providing 24-hour high-quality service

User-friendly online submission system

Fair and swift peer-review system

Efficient typesetting and proofreading procedure

Display of the result of downloads and visits, as well as the number of cited articles Maximum dissemination of your research work

Submit your manuscript at: http://papersubmission.scirp.org/

Or contact ojim@scirp.org 